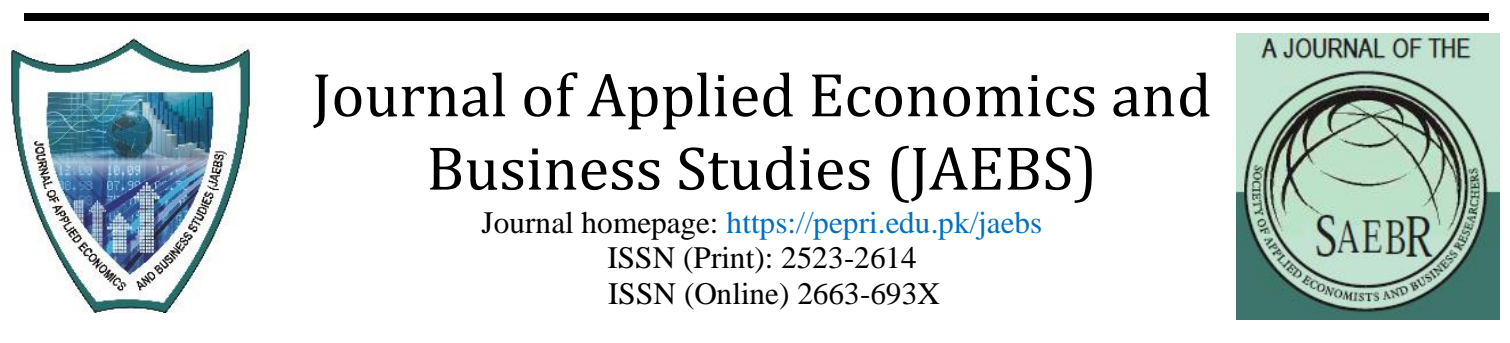

\title{
Product Line Diversification and Its Impact on Firm Performance
}

Zia ur Rehman $\mathrm{PhD}^{1}$, Asad Khan ${ }^{2}$, Rafique Ahmed Khuhro ${ }^{3}$ and Abdul Ghafoor Khan ${ }^{4}$

${ }^{1}$ Assistant Professor Department of Management Sciences, University of Haripur, Pakistan
${ }^{2}$ Lecturer, Department of Management Sciences, University of Haripur, Pakistan
${ }^{3}$ Assistant Professor, Department of Management Sciences, University of Haripur, Pakistan
${ }^{4}$ Lecturer, Department of Management Sciences, Comsats University, Abbottabad Campus

ABSTRACT
The objective of the study is to measure product diversification's
impact on insurance firm's financial performance in Pakistan.
Analysis are carried out to examine how ownership structure,
capitalization, group membership, firm size, diversification
across business lines, industry concentration affects firm's
financial performance. Data from $2009-2019$ is collected to
measure the impact of diversification (entropy) on the risk-
adjusted returns. Findings of the study reveal that business line
diversification has strong positive effect onfirm performance(for
both ROA and ROE) which means that diversified firms perform
better than non-diversified firms. For managers these findings
are useful as they propose the need for diversification,
capitalization, increase in size and group affiliation to enhance
firm profitability.

Keywords

Product line

Diversification,

Firm

Performance,

Return on

Assets, Return

on Equity

JEL

Classification

G32

\section{Introduction}

Globalization, de-regulation of markets, advancement in technology has opened up borders for businesses across the globe. Theoretically, product diversification is considered to be an important strategy for maximizing firm value and minimizing risk, but it also has certain costs associated with it. For example, the total cost for producing each unit of a product will be higher as compared to system where the production process is shared and associated with concentration (Teece, 1980). The benefits of diversification can be realized if the internal governance mechanisms are efficient (Williamson, 1985). In literature, product diversification has been analyzed with respect to property-liability or life-health insurance companies or companies that diversify across both types (Meador, Ryan \& Schellhorn, 2000; Hardwick and Adams, 
2002; Cummins, Weiss, Xie \& Zi, 2010; Shim, 2011; Che, Liebenberg, Liebenberg \& Powell; Ai, Bajtelsmit \& Wang 2018).

Despite several studies on the insurance industry, still there is limited evidence with respect to the performance effect of product diversification. Several studies have focused on the analyzing the relationship between business line diversification and nonlife-insurers (Elango, Ma \& Pope, 2008; Pavic \& Pervan, 2010; Lee \& Kang, 2015; Ai et al., 2018) To the best of our knowledge, we found no empirical evidence with respect to the product diversification's impact on insurance firm's performance in Pakistan.

Since deregulation in the Pakistani markets, many insurance companies attempted to diversify across non-life and life insurance products. The demand for both these insurance products is increasing as customers are realizing the need and importance of insurance, life or non-life in order to protect their future against uncertainties. This is the main motivation behind doing research on business line diversification's impact on insurance firm's performance as the empirical results till now are still unclear. Hence, the study aims to analyze business line diversification's impact on insurance firm's performance in Pakistan. Following previous empirical studies and theory, this study attempted to test two theories: "strategic focus theory and conglomeration theory". The strategic focus theory assumes that diversification has a negative effect on firm performance due to its associated costs whereas the conglomeration theory focuses on the benefits of diversification leading to positive effect on firm performance.

The study contributes in the following ways. First, it adds to the existing literature by providing further evidence from a developing country as the empirical results pertaining to diversification's influence on firm performance are mixed. Second, for managers, the findings of the study are equally important in formulating and implementing business strategies, diversification plans in order to position them better in the market. Third, this study helps in providing important information that will help policy makers at government and institutional level in forming polices aimed at incentivizing or disincentivizing product diversification, grouping, firm size, non-life diversification, competitive policies and capitalization that will greatly help in improving the financial performance of insurance firms.

\section{Literature Review}

\subsection{The theory - firm value and diversification}

The views of business managers, stockholders and creditors greatly differ on the benefits of diversification. Managers, for example, would like their respective firms to diversify internally or externally in order to minimize the overall firm-specific risk. Likewise, creditors while protecting their own interests may want the firm to diversify its investments in such a manner that will increase the cash flow for the business thus reducing the risk delayed payments and loan default. Additionally, shareholders 
owning a diversified portfolio would not like the firm to diversify further if they are able to do this inexpensively in their own respective investment portfolios.

\subsection{Why Diversify}

According to Montgomery (1994) the three important reasons based on theory due to which firms prefer to diversify. These theoretical perspectives are the market power, resource-based view and agency theory. Looking through the resource-based perspective, firms diversify into those areas where there is excess capacity of capabilities and resources that are easily and efficiently transferable across industries. Here the focus is on scope economies whereby a diversified firm organizes economic activities efficiently (Penrose \& Penrose, 2009). For instance, same marketing and distribution channels can be used to firm to market its products. Similarly, firms may be able to utilize the services and skills of corporate legal and financial staff members to support business operations in various industries. Matsusaka (2001) argued that organizations use diversification strategy to explore good matches between their organizational competences and external opportunities thus resulting in entering new business lines and leaving old ones that are not profitable.

From the agency theory perspective, diversification strategy can be viewed as the pursuance of manager's self-interest at the cost of shareholders. The theory further explains the possible motivation behind manager's decision to diversify is that it is likely to (i) increase manager's allowances and pay (Jensen \& Murphy, 1990), increase in their stature and power (Jensen, 1986); (ii) make their respective job positions more secure within organization through investment in projects that the specific skills that they possess thus making the firm dependent on them (Shleifer \& Vishny, 1989); or (iii) reduce their own investment portfolio risk by lowering firm risk as managers are unable to lower their own portfolio risk through diversification (Amihud \& Lev, 1981).

Lastly, the motivation for the firm to diversify is to seek market power. In a study, (Villalonga, 2004) presented three non-competitive reasons for the firm to diversify. Firstly, profits earned in one industry or sector can be used for predatory pricing in another by the firm. Secondly, diversification will allow firms to conspire with other firms that are simultaneously in competition with the firm in different markets. Lastly, firms may use diversification strategy to drive out small competitors through reciprocal buying with other large businesses.

Empirically, numerous studies have been undertaken to measure diversified firm's performance as compared to specialized firms in the last three decades or so. Hoyt and Trieschmann (1991) were most probably the first researchers to study the impact of strategic focus and diversification on insurance firms. The findings of their study revealed that specialized insurance provider performed better over other insurers during the sample period. Meador et al. (2000) analyzed link between output choices that the 
firm makes and X-efficiency and concluded that diversification across various insurance and investment products lines by insurance providers led to greater $\mathrm{X}$ efficiency as compared to insurance providers that used a more focused production strategy. Ai et al., (2018) found that enterprise risk management (ERM) is an important determinant for property and casualty insurers and in insurance firms having quality ERM programs, the effect of product diversification on firm performance was significant and positive. While providing proof on the validity of strategic focus theory versus the conglomeration theory Berger, Cummins, Weiss and $\mathrm{Zi}$ (2000) concluded that in some insurance providers conglomeration diversification hypothesis dominates whereas in others it is strategic focus hypothesis that dominates. Moreover, Liebenberg and Sommer (2008) analyzed the effect of business line related diversification on firm performance and concluded that undiversified firms performed better than diversified firms. Additionally, they also highlighted that size and capitalization positively affects performance i.e. unaffiliated insurers perform better than insurance groups and stock insurers performance is comparatively better than mutual insurers. Cummins et al. (2010) analyzed the US insurance firms with particular focus on economies of scope. The focus of their analysis was to find out insurers who provide diversified are better off of insurers that provided specialized products. They concluded that although cost scope economies are realized by property-liability insurers, but they are quickly equalized by the resulting revenue scope diseconomies. In contrast, they find both revenue and cost diseconomies are experiences by firms that provide life-health insurance and concluded strategic focus is given more significance over diversification by insurance firms. Krivokapić, Njegomir, and Stojić (2017) found that diversification impact on insurer's performance is positive. Ai et al. (2018) found significant positive effect on firm performance. Che et al. (2017) also found that in terms of return on investment the performance of diversified firms is better as compared to nondiversified firms, but diversified firms underperform than non-diversified firms with respect to underwriting profitability.

On the other hand, Cummins and Nini (2002), concluded that diversification has inverse effect on firm profitability. Pavić and Pervan (2010) and Lee and Kang (2015) also found that diversification has a significant negative influence on profitability. Lee (2017) also analyzed product diversification's impact on firm performance among insurance firms and found significant negative effect on insurer's performance. Shim (2011) focused on the merger and acquisitions related diversification's impact on performance. The findings of the study revealed the acquirer firms experienced volatility in their earnings probably due to increased agency problems and frictions.

$\mathrm{Li}$ and Greenwood (2004) concluded that mutual forbearance and market structuration is advantageous but not diversification. Elango et al. (2008) found nonlinear and complex relationship between firm performance and product diversification. 
They further added that the benefits of diversification for the firm are tied to the degree of insurer's geographic diversification. Berry-Stölzle, Liebenberg, Ruhland, and Sommer (2012) examined business line diversification impact on firm performance and concluded that companies operating in volatile markets diversify less. With respect to managerial discretion hypothesis, they found support for diversification prediction when the measure of unrelated business line diversification was used and concluded that stock insurers should do more diversification than mutual insurers. The reason being, although the level of total diversification is very high for mutual insurers yet compared to stock insurers they engage is very less unrelated diversification.

Although most of the empirical results favour the strategic focus hypothesis over diversification hypothesis, still there is lack of consistency internationally. This, in addition to lack of similar studies generally in developing countries and particularly in Pakistani insurance industry, worked as a motivator for conducting analytical study on this topic.

Based on the earlier studies and particularly on the study of Liebenberg and Sommer (2008), we attempt to analyze the strategic focus and conglomeration hypothesis

$\mathrm{H}_{1}$ Diversification positively influences firm performance (Conglomeration)

$\mathrm{H}_{2}$ Diversification negatively influences firm performance (Strategic focus)

Diversification and its relationship with firm performance relationship can be expressed in the following form: "Performance $=\mathrm{f}$ (diversification; firm and industry characteristics)" (adapoted from Liebenberg \& Sommer, 2008).

Hence, firm performance is also influenced by other industry and firm characteristics apart from diversification. The variables used in this study include firm performance (dependent variable) whereas the explanatory variables include product diversification (entropy) and firm specific and industry variables like firm size, ownership structure, capitalization, industry concentration.

\section{Methodology}

\subsection{Sample and Data}

Since the focus of our study was on non-life insurance firms, therefore only nonlife insurance firms were considered. The final sample comprised of 28 firms and data for the selected firms was collected from 2009-2019. The reason for focusing on insurance firms is that in Pakistan since deregulation of financial markets numerous opportunities arose which led to rise in new entrants into the insurance industry and many firms implemented diversification strategies to generate cost savings by cross selling products, entering into new business lines and markets, create hybrid products according to individual customer needs. Moreover, some researchers are of the view since diversification acts as a natural hedging mechanism therefore, it potentially holds 
a special value for insurance firms to reduce their reliance on formal hedging instruments for risk mitigation (Cummins, Philips \& Smith, (2001). For this study, those companies were selected that remained listed throughout the study period. Data was collected from State Bank of Pakistan database which contains the financial data for all listed firms. Data related to ownership structure, group affiliation was collected from company's annual reports and websites.

Since data contained characteristics of both time series and cross-sectional data therefore panel regression was used. Panel data is useful because "it reduces the collinearity between the independent variable, improves the efficiency of statistical estimates and also provide a large number data points" (Saleh et al., 2008). The dependent variable representing firm performance is ROA and ROE whereas entropy (product diversification) is the main independent variable. In addition to this the model also contains other explanatory variables; firm size, specific line market concentration, share of life premiums, capitalization, and two dummy variables: GP and DMST.

\subsection{Dependent variable}

Since the aim of the study is measuring product diversification's impact on firm performance and firm performance being a dependent variable, therefore two common measures i.e. Return on equity (ROE) and Return on assets (ROA) are used to measure the performance of insurance firms. These measures are commonly used in literature for measuring insurer's financial performance (Amit \& Livnat, 1988; Lai \& Limpaphayom, 2003; Pottier \& Sommer, 1999; Wang, Jeng, \& Peng, 2007). Estimations on both performance measures was carried which is consistent with methodology of Liebenberg and Sommer (2008). Risk adjusted return of ROA (SDROA) and risk adjusted ROE (SDROE) was used to incorporate the impact of risk on returns. For this purpose, ROA and ROE was divided by standard deviation (SD) of observed ROA and ROE over the last five years.

\subsection{Explanatory variables}

Product diversification which is an important variable in the context of our study is measured through the measure used by Liebenberg and Sommer (2008) i.e. "ENTROPY" which differentiate firms operating in one line of business from firms operating many lines of businesses. Furthermore, we used the "entropy measure (E) following Elango et al. (2008) and Pavić and Pervan (2010). This entropy measures not only considers the number of products being offered by the company but also the weighted distribution of a company's share in each product line.

The entropy measure is calculated as

$$
\mathrm{E}=\sum_{\mathrm{i}=1}^{\mathrm{I}_{\mathrm{L}}} \mathrm{P}_{\mathrm{i}} \ln \frac{1}{\mathrm{P}_{\mathrm{i}}}
$$


where $\mathrm{Pi}$ is the percentage of an insurer's premiums written on product line $\mathrm{i}$ and IL is number of insurance lines. If an insurance company operates in only one insurance line (i.e., exclusively focused company), the coefficient of entropy will take the value zero $(E=0)$. The maximum value that the entropy measure can take in a situation where a company has the same shares in all lines, is calculated as the natural logarithm of the number of insurance lines in the industry, $\ln ($ IL)" (Krivokapić et al., 2017).

Firm size also used in earlier studies positively affects firm performance (Cummins \& Nini, 2002; Liebenberg \& Sommer, 2008). Natural logarithm of total assets is used for measuring firm size. Based on empirical results from earlier studies we also expect positive influence of firm size on insurer's performance.

Those insurance firms that are well capitalized are regarded as safe companies with respect to bankruptcy by rating agencies. For this reason, potential as well current insurance buyers are willing to pay additional premiums to the insurance providers as they are less likely to go bankrupt (Sommer, 1996). Capital to asset ratio is used as a measure for firm capitalization (CAP). We expect a positive effect of firm capitalization on insurer's performance.

The structure-conduct-performance paradigm implies that market performance is determined by market conduct, which in turn directly and indirectly depends on market structure. According to S-C-P hypothesis, higher profitability in any market is associated with anticompetitive behavior induced by higher market concentration (Njegomir \& Stojić, 2010). The support for the S-C-P hypothesis is abundant (see e.g.Bajtelsmit and Bouzouita (1998); Chidambaran, Pugel, and Saunders (1997); Elango et al. (2008); Njegomir and Stojić (2011)). To capture the impact of the competitiveness of firms' markets on performance, we first calculate a HerfindahlHirschman concentration index for each line of business $(j=1$ to

IL) across all firms ( $i=1$ to $n$ ) in each year $t$

$$
\mathrm{HHI}_{\mathrm{jt}}=\sum_{\mathrm{i}=1}^{\mathrm{n}}\left(\frac{\mathrm{DPW}_{\mathrm{ijt}}}{\mathrm{DPW}_{\mathrm{jt}}}\right)
$$

The larger the value of HHIjt, the more concentrated is that line of business and 'the greater is the potential for super-normal profits' (Liebenberg \& Sommer, 2008). We then calculate each firm's $(i=1$ to $n$ ) participation in each line of business $(j=1$ to IL) for each year $\mathrm{t}$

$$
W_{i j t}=\frac{D P W_{i j t}}{D P W_{j t}}
$$

Using wijt as weights we then calculate the weighted sum of a firm's exposure to industry concentration across all of the lines in which it operates 


$$
\mathrm{WCONC}_{\mathrm{it}}=\sum_{\mathrm{j}=1}^{28} \mathrm{w}_{\mathrm{ijt}} \mathrm{HHI}_{\mathrm{jt}}
$$

Firms with small values for WCONC are exposed to competitive business lines". We expect WCONC to positively affect firm performance.

In the modern-day financial services marketplace, group affiliation is an important firm characteristic that is very common now days (Elango et al., 2008). There is a presence of both affiliated and unaffiliated insurance companies in the Pakistani insurance market.

Consistent with the outcomes of earlier studies by Cummins and Sommer (1996), Liebenberg and Sommer (2008), we also expect group affiliation to negatively affect firm performance. Group affiliation is measure through a dummy variable (GP) having a value equal to 1 if it a group affiliated and 0 otherwise.

Insurance companies in our sample have a diverse ownership structure i.e. public/private and majority owned by foreign or domestic owners. Since we are considering only listed firms that are publicly owned therefore, we need to control ownership structure with respect to majority of ownership i.e. domestic or foreign. For controlling ownership structure in this respect, we used a dummy variable DMST which indicates that the firm is domestic majority owned. We assume companies that are majority foreign owned shall outperform companies that are majority domestic owned due to greater managerial expertise, know-how and financial strength (Dorfman, 1998; Puri, 2007).

\subsection{Descriptive Statistics}

According to Table 1, showing variable's descriptive statistics the mean average of ROA is $4.129 \%$ whereas as the mean average of ROE $7.029 \%$. The mean average of firm capitalization is $47.28 \%$, the standard deviation values indicate that ROA, ROE and CAP are more volatile as compared to other variables.

Table 1. Descriptive statistics.

\begin{tabular}{llllll}
\hline & Mean & Median & Max & Min & SD \\
\hline ROA & 4.129 & 4.820 & 145.360 & -87.000 & 17.563 \\
ROE & 7.029 & 10.360 & 162.910 & -204.510 & 27.255 \\
SDROA & 0.234 & 0.273 & 8.222 & -4.921 & 0.993 \\
SDROE & 0.258 & 0.381 & 5.989 & -7.519 & 1.002 \\
ENTROPY & 1.413 & 0.966 & 2.811 & 0.000 & 0.258 \\
SIZE & 5276425 & 1421863 & 42287139 & 6306 & 8361969 \\
CAP & 47.2872 & 44.86 & 161.64 & -5.86 & 20.79188
\end{tabular}




$\begin{array}{llllll}\text { WCONC } & 0.560 & 0.059 & 4.942 & 0.000 & 1.008 \\ \text { GP } & 0.597 & 0.988 & 1.000 & 0.000 & 0.474 \\ \text { DMST } & 0.890 & 1.000 & 1.000 & 0.000 & 0.413\end{array}$

Note: Return on Assets (ROA), Return on Equity (ROE), Risk Adjusted Return on Assets (SDROA), Risk Adjusted Return on Equity (SDROE), Firm Size (SIZE), Firm Capitalization (CAP), Exposure to Industry competitiveness/concentration (WCONC), Group Affiliation (GP), Domestic majority owned (DMST)

\subsection{Regression models}

In this study a series of time series, pooled, time and cross-sectional OLS regressions were performed. Initially our focus was on finding out whether any type of diversification positively/negatively affects the performance of the firm. Following a methodology similar to Berger and Ofek (1995) ENTROPY is used as an indicator variable to identify whether "an insurance firm operates in one line (ENTROPY $=0)$ or multiple lines (ENTROPY $=1$ ) in any particular year". The basic equation to measure product diversification impact on firm performance is given below:

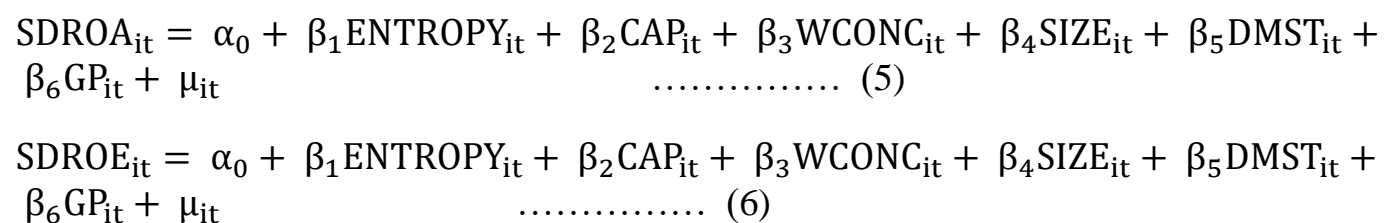

Both above mentioned equations are estimated twice, initially with year dummies (OLS1) followed by year and line dummies (OLS2). In addition to OLS other techniques are also used to test robustness of the model and results. However, recent empirical evidence suggests that diversification discounts in earlier studies has credited the discount observed to endogeneity bias. If entropy measure is not correlated with the error term, then the estimates of entropy measuring its impact on ROA will be inconsistent and biased. The problem of endogeneity arises due to a number of factors like simultaneity bias, measurement errors, omitted variables etc. (Wooldridge, 2016). For testing exogeneity of the entropy measure, Hausman test is conducted, the results of which rejects the null hypothesis that entropy measure is exogenous. In literature we have found that researchers focusing on diversification discounts have used different methods for controlling endogeneity bias (Campa \& Kedia, 2002; Laeven \& Levine, 2007). One of these techniques is the fixed effects estimation that is commonly used by researchers in this regard. One of the main advantages of this technique is that it allows to control the omitted or unobservable firm specific effects which may be related with other independent variables used in the model. However, the fixed effects model is disadvantageous in situations due to its limited applicability where the key independent variables show sufficient within firm variations. "If the explanatory variables remain the same over time, they are swept away during the time-demeaning process which leads to the elimination of time-invariant unobserved effects or 
explanatory variables that do not change substantially over time, the fixed effects technique can lead to estimates that are not precise and accurate" (Wooldridge, 2016). Because ENTROPY being almost time invariant, therefore, fixed effect estimation is not used here. We have 28 firms in our sample. Of these 28 firms 5 firms are those that only operate in one line at least in one year. Off these 5 firms, 4 firms are those that operate only in single line during the period under investigation. Thus variation occurs in only 1 firm or 20 percent of all firms.

The second technique that is mostly used for controlling endogeneity bias is estimating equation 1 and 2 using a 2-stage least square technique and Heckman technique (Campa \& Kedia, 2002; Laeven \& Levine, 2007). In 2SLS technique, the ENTROPY measure first is regressed on other explanatory variables in Equation 1 and 2 and a set of instruments that do not apparently appear in Equation 1 and 2. The second stage of 2SLS comprises of estimating equation 1 and 2 using predicted values of the ENTROPY measure derived from the first stage of 2SLS. As far as the Heckman approach is concern it follows procedure similar to 2SLS but it also includes the selection of parameter on self-basis which is calculated from the information extracted from the first stage of 2SLS. However, both methods require instrument selection of the ENTROPY measure. Campa and Kedia (2002) suggested an "instrument set comprising lagged, current and historically averaged measures of industry growth, firm characteristics and general economic growth". We followed same methodology as adopted by Liebenberg and Sommer (2008) for the constructing the instrumental variable set where instrument variable set "consists of lagged values of firm characteristics included in Equation (1), 5-year historical averages of firm characteristics included in Equation (1), 1-year growth in direct premiums written for the $\mathrm{P} / \mathrm{L}$ industry, 1-year growth in Pakistan gross domestic product, firm age, firm reinsurance use, and an index that captures the attractiveness of a firm's markets to single-line insurers". To be included in the instrumental variable set a candidate must need two important conditions. First, the candidate instrument must be relevant i.e. the candidate instrument must have higher partial correlation with ENTROPY. The second condition is concerned with validity of the instrument, which means that the candidate instrument is unrelated with the error term in Equation 1 and 2. Wald test was used for the joint importance of excluded instruments to measure the relevance of instruments. As per the null hypothesis of Wald test, the hypothesis was that instruments are jointly not significant. Since different candidates were successful in relevance test for the instrument, therefore we manage to test the validity of the instruments for over identifying restrictions using Hansen's J-test. Null hypothesis of Hansen's J-test is there is correlation between the instruments and the error term i.e. there are exogenous. The attractiveness of insurer's market to single line insurance firm's index, age and 
reinsurance use are the only candidates that met the conditions of validity and relevance.

\section{Empirical Results}

In this section, empirical results and discussion on the results is presented. Initial results favour the conglomeration hypothesis, that is both the SDROA and SDROE have a positive relationship with entropy in all estimations, therefore we can conclude that product diversification effect on firm performance is positive. Empirical studies from Hoyt and Trieschmann (1991), Meador et al. (2000) and Krivokapic et al., (2017) also found product diversification's positive impact on insurer's performance.

Secondly, firm size also has a significant positive influence on both measures of firm performance in all estimations. Firm performance is positively affected by growth in total assets. These findings are consistent with respect to large firms as they exploit economies of scales and have comparatively lower default risk. Empirically, Liebenberg and Sommer (2008) also concluded firm size positively impacting firm financial performance.

Table: 2 Regression Results (Dependent Variable SDROA)

\begin{tabular}{lcccc}
\hline & OLS1 & OLS2 & 2SLS & HECKMAN \\
\hline Constant & $-0.893 * * *$ & $-0.712 * * *$ & $-0.599 * * *$ & $-0.469 * * *$ \\
& $(0.024)$ & $(0.023)$ & $(0.025)$ & $(0.009)$ \\
ENTROPY & $3.721 * * *$ & $2.989 * * *$ & $2.661 * * *$ & $2.311 * * *$ \\
& $(0.001)$ & $(0.003)$ & $(0.013)$ & $(0.007)$ \\
SIZE & $0.137 * * *$ & $0.121 * * *$ & $0.108 * * *$ & $0.104 * * *$ \\
& $(0.000)$ & $(0.000)$ & $(0.002)$ & $(0.001)$ \\
CAP & $0.020 * * *$ & $0.017 * * *$ & $0.013 * * *$ & $0.015 * * *$ \\
& $(0.004)$ & $(0.002)$ & $(0.012)$ & $(0.003)$ \\
WCONC & $0.612 * *$ & $0.501 * *$ & 0.487 & $0.461 * *$ \\
& $(0.049)$ & $(0.021)$ & $(0.005)$ & $(0.008)$ \\
DMST & -0.012 & -0.01 & -0.008 & -0.004 \\
& $(0.002)$ & $(0.001)$ & $(0.000)$ & $(0.001)$ \\
GP & $-0.019 * * *$ & $-0.018 * * *$ & $-0.013 * *$ & $-0.011 * * *$ \\
& $(0.001)$ & $(0.001)$ & $(0.002)$ & $(0.001)$ \\
Hansen $J$-statistic & & & 1.216 & \\
Wald test Statistic & & & $378.1 * * *$ & \\
Self-Selection & & & & $0.032 * * *$ \\
parameter & & & & $0.003)$ \\
Adjusted $R^{2}$ & 0.23 & 0.24 & 0.27 & 0.25 \\
\hline
\end{tabular}

Significance level at $1 \%, 5 \%$, and $10 \%$ is denoted by $* * *, * *$, and $*$, respectively, $p$-value in parenthesis

Firm exposure to industry concentration measured through WCONC has a strong positive effect on firm performance across all models. These findings are significant in 
supporting our hypothesis that businesses operating in concentrated business lines earn higher profits by charging higher prices than businesses operating in less concentrated business lines. Liebenberg and Sommer (2008) and Krivokapic et al., (2017) also found positive impact of firm exposure to industry concentration on firm performance.

CAP's coefficient is positive and significant across all models for both measures of firm performance. This positive relationship supports the hypothesis that risk-averse policyholders paying higher prices to safe insurers will lead to a higher risk-adjusted performance. Empirically, Sommer (1996) also found positive effect of firm capitalization on firm performance.

Additionally, dummy variable DMST used to test whether domestic companies perform differently as compared to companies that are in foreign ownership is found insignificant. The coefficient of group affiliation (GP) is negative but significant. Empirical studies from Cummins and Sommer (1996) and Liebenberg and Sommer (2008) also found negative relationship between group affiliation and firm performance. The negative value of GP can be attributed to lower prices made by the option to let a member fail, managerial discretion costs and other conglomeration related costs.

Table:3 Regression Results (Dependent Variable SDROE)

\begin{tabular}{lcccc}
\hline & OLS1 & OLS2 & 2SLS & HECKMAN \\
\hline Constant & $-1.110 * * *$ & $-0.994 * * *$ & $-0.859 * * *$ & $-0.773 * * *$ \\
ENTROPY & $(0.011)$ & $(0.009)$ & $(0.007)$ & $(0.009)$ \\
& $2.931 * * *$ & $2.016 * * *$ & $2.009 * * *$ & $1.891 * * *$ \\
SIZE & $(0.000)$ & $(0.021)$ & $(0.006)$ & $(0.006)$ \\
& $0.209 * * *$ & $0.197 * * *$ & $0.179 * * *$ & $0.176 * * *$ \\
CAP & $(0.000)$ & $(0.000)$ & $(0.000)$ & $(0.003)$ \\
& $0.013 * * *$ & $0.012 * * *$ & $0.010 * * *$ & $0.008 * * *$ \\
WCONC & $(0.004)$ & $(0.001)$ & $(0.007)$ & $(0.002)$ \\
& $0.591 * *$ & $0.471 * *$ & 0.458 & $0.398 * *$ \\
DMST & $(0.042)$ & $(0.026)$ & $(0.019)$ & $(0.005)$ \\
& -0.010 & -0.009 & -0.007 & -0.006 \\
GP & $(0.080)$ & $(0.130)$ & $(0.112)$ & $(0.201)$ \\
& $-0.015 * * *$ & $-0.014 * * *$ & $-0.010 * *$ & $-0.013 * * *$ \\
Hansen $J$-statistic & $(0.000)$ & $(0.001)$ & $(0.001)$ & $(0.002)$ \\
Wald test Statistic & & & 1.049 & \\
Self-Selection parameter & & & $299.1 * * *$ & \\
& & & & $0.029 * * *$ \\
Adjusted $R^{2}$ & 0.24 & 0.26 & 0.30 & $(0.004)$ \\
\hline Significance level at $1 \%, 5 \%$, and $10 \%$ is denoted by $* * * * *$, and $*$, respectively, $p$-value in parenthesis
\end{tabular}




\section{Conclusion}

The objective of the study is to measure product diversification's impact on insurance firm's financial performance in Pakistan. Analysis were carried out to examine how ownership structure, capitalization, group membership, firm size, diversification across business lines, industry concentration affects firms financial performance. Data from 2009-2019 is collected to measure the impact of diversification (entropy) on the risk-adjusted returns.

Based on our findings, we conclude that our results are similar to similar kind of studies conducted on developing countries. Dummy variables apart from GP used in this study has an insignificant impact which emphasize on the need of urgent action to implement respective measures taken by the government to develop the insurance industry in particular and other financial services in general. For policy makers in Pakistan, the findings are significant in the sense that currently the economy of Pakistan desperately needs financial resources that would help in boosting economic growth considering the fact the economy is already overburdened by huge foreign and domestic debt and limited capital stocks available.

For the management of insurance firms in Pakistan, the findings of the study are equally important in formulating and implementing business strategies, diversification plans in order to position them better in the market. For government also the finding provides important information that will help in forming polices aimed at incentivizing or disincentivizing product diversification, grouping, firm size, non-life diversification, competitive policies and capitalization that will greatly help in improving the financial performance of insurance firms. Overall performance of insurance industry is also of great interest to the government apart from the insurance firms themselves because greater good can be achieved socially and morally if the insurance industry performs well.

As far as the limitation of the studies is concerned, one possible limitation of the study findings can be the insignificant relationship appearing in the models for most of the control variables. Furthermore, research on the associated cost of both product as well as geographic diversification would be of great help to the managers in devising strategies that are cost effective thus leading better financial performance. Future research should also focus on impact of geographic diversification on financial performance. Additionally, future research can also conducted involving more countries which will help in getting more consistent cross-country estimators 


\section{References}

Ai, J., Bajtelsmit, V., \& Wang, T. (2018). The combined effect of enterprise risk management and diversification on property and casualty insurer performance. Journal of risk and insurance, 85(2), 513-543.

Amihud, Y., \& Lev, B. (1981). Risk Reduction as a Managerial Motive for Conglomerate Mergers. Bell Journal of Economics, 12(2), 605-617.

Amit, R., \& Livnat, J. (1988). Diversification and the risk-return trade-off. Academy of Management Journal, 31(1), 154-166.

Bajtelsmit, V., \& Bouzouita, R. (1998). Market structure and performance in private passenger automobile insurance. Journal of Risk \& Insurance, 65(3), 503-514.

Berger, A. N., Cummins, J. D., Weiss, M. A., \& Zi, H. (2000). Conglomeration versus strategic focus: Evidence from the insurance industry. Journal of financial intermediation, 9(4), 323-362.

Berger, P. G., \& Ofek, E. (1995). Diversification's effect on firm value. Journal of financial economics, 37(1), 39-65.

Berry-Stölzle, T. R., Liebenberg, A. P., Ruhland, J. S., \& Sommer, D. W. (2012). Determinants of corporate diversification: evidence from the property-liability insurance industry. Journal of risk and insurance, 79(2), 381-413.

Campa, J. M., \& Kedia, S. (2002). Explaining the diversification discount. the Journal of Finance, 57(4), 1731-1762.

Che, X., Liebenberg, A. P., Liebenberg, I. A., \& Powell, L. S. (2017). Decomposing diversification effect: evidence from the US property-liability insurance industry. Insurance Markets and Companies, 8(1), 16-28.

Chidambaran, N., Pugel, T. A., \& Saunders, A. (1997). An Investigation of the Performance of the US Property-Liability Insurance Industry. Journal of risk and insurance, 64(2), 371-382.

Cummins, J. D., \& Nini, G. P. (2002). Optimal capital utilization by financial firms: Evidence from the property-liability insurance industry. Journal of Financial Services Research, 21(1), 15-53.

Cummins, J. D., \& Sommer, D. W. (1996). Capital and risk in property-liability insurance markets. Journal of Banking \& Finance, 20(6), 1069-1092.

Cummins, J. D., Weiss, M. A., Xie, X., \& Zi, H. (2010). Economies of scope in financial sservices: A DEA efficiency analysis of the US insurance industry. Journal of Banking \& Finance, 34(7), 1525-1539.

Dorfman, M. S. (1998). Introduction to risk management and insurance: Pearson Education.

Elango, B., Ma, Y. L., \& Pope, N. (2008). An investigation into the diversificationperformance relationship in the US property-liability insurance industry. Journal of risk and insurance, 75(3), 567-591. 
Hardwick, P., \& Adams, M. (2002). Firm size and growth in the United Kingdom life insurance industry. Journal of risk and insurance, 69(4), 577-593.

Hoyt, R. E., \& Trieschmann, J. S. (1991). Risk/return relationships for life-health, propertyliability, and diversified insurers. Journal of risk and insurance, 322-330.

Jensen, M. C. (1986). Agency costs of free cash flow, corporate finance, and takeovers. The American economic review, 76(2), 323-329.

Jensen, M. C., \& Murphy, K. J. (1990). Performance pay and top-management incentives. Journal of political Economy, 98(2), 225-264.

Krivokapić, R., Njegomir, V., \& Stojić, D. (2017). Effects of corporate diversification on firm performance: evidence from the Serbian insurance industry. Economic research-Ekonomska istraživanja, 30(1), 1224-1236.

Laeven, L., \& Levine, R. (2007). Is there a diversification discount in financial conglomerates? Journal of financial economics, 85(2), 331-367.

Lai, G. C., \& Limpaphayom, P. (2003). Organizational structure and performance: evidence from the nonlife insurance industry in Japan. Journal of risk and insurance, 70(4), 735-757.

Lee, C.-Y. (2017). Product diversification, business structure, and firm performance in Taiwanese property and liability insurance sector. Journal of Risk Finance, 18(5), 486-499.

Lee, S. U., \& Kang, J. (2015). Technological diversification through corporate venture capital investments: Creating various options to strengthen dynamic capabilities. Industry and Innovation, 22(5), 349-374.

Li, S. X., \& Greenwood, R. (2004). The effect of within-industry diversification on firm performance: synergy creation, multi-market contact and market structuration. Strategic management journal, 25(12), 1131-1153.

Liebenberg, A. P., \& Sommer, D. W. (2008). Effects of corporate diversification: Evidence from the property-liability insurance industry. Journal of risk and insurance, 75(4), 893-919.

Matsusaka, J. G. (2001). Corporate diversification, value maximization, and organizational capabilities. The Journal of Business, 74(3), 409-431.

Meador, J. W., Ryan Jr, H. E., \& Schellhorn, C. D. (2000). Product focus versus diversification: Estimates of X-efficiency for the US life insurance industry. Performance of financial institutions: efficiency, innovation, regulation, 175-199.

Montgomery, C. A. (1994). Corporate diversificaton. Journal of Economic perspectives, $8(3), 163-178$.

Njegomir, V., \& Stojić, D. (2010). Determinants of insurance market attractiveness for foreing investments: The case of ex-Yugoslavia. Economic research-Ekonomska istraživanja, 23(3), 96-110. 
Njegomir, V., \& Stojić, D. (2011). Liberalisation and market concentration impact on performance of the non-life insurance industry: the evidence from Eastern Europe. The Geneva Papers on Risk and Insurance-Issues and Practice, 36(1), 94-106.

Pavić, I., \& Pervan, M. (2010). Effects of corporate diversification on its performance: The case of Croatian non-life insurance industry. Ekonomska misao i praksa(1), 49-66.

Penrose, E., \& Penrose, E. T. (2009). The Theory of the Growth of the Firm: Oxford university press.

Pottier, S. W., \& Sommer, D. W. (1999). Property-liability insurer financial strength ratings: differences across rating agencies. Journal of risk and insurance, 621-642.

Puri, L. (2007). Introduction to the trade and development aspects of insurance services and regulatory frameworks. Trade and development aspects of insurance services and regulatory frameworks, 1-5.

Saleh, M., Zulkifli, N., \& Muhamad, R. (2008). An empirical examination of the relationship between corporate social responsibility disclosure and financial performance in an emerging market. Paper presented at the 16th Annual Conference on Pacific Basin Finance Economics Accounting Management (PBFEAM).

Shim, J. (2011). Mergers \& acquisitions, diversification and performance in the US property-liability insurance industry. Journal of Financial Services Research, 39(3), 119-144.

Shleifer, A., \& Vishny, R. W. (1989). Management entrenchment: The case of managerspecific investments. Journal of financial economics, 25(1), 123-139.

Sommer, D. (1996). The impact of firm risk on property-liability insurance prices. Journal of Risk \& Insurance, 63(3), 501-514.

Teece, D. J. (1980). Economies of scope and the scope of the enterprise. Journal of economic behavior \& organization, 1(3), 223-247.

Villalonga, B. (2004). Diversification discount or premium? New evidence from the business information tracking series. the Journal of Finance, 59(2), 479-506.

Wang, J. L., Jeng, V., \& Peng, J. L. (2007). The impact of corporate governance structure on the efficiency performance of insurance companies in Taiwan. The Geneva Papers on Risk and Insurance-Issues and Practice, 32(2), 264-282.

Williamson, O. (1985). E., 1985, The Economic Institutions of Capitalism: firms, markets, relational contracting. New York, NY: Free Press.

Wooldridge, J. M. (2016). Introductory econometrics: A modern approach (5th ed.): Nelson Education. 